\title{
EFFECT OF ETHYLENE ANTAGONIST SILVER THIOSULPHATE ON THE FLOWER LONGEVITY OF Clarkia pulchella PURSH.
}

\author{
Riyaz Ahmad DAR, Inayatullah TAHIR* \\ Department of Botany, University of Kashmir \\ 190006 Srinagar (Jammu and Kashmir), India \\ Received: January 2017; Accepted: Mai 2018
}

\begin{abstract}
An experiment was conducted to study the effect of different concentrations of silver thiosulphate (STS) on flower longevity of Clarkia pulchella Pursh. The buds were subjected to 0.1, 0.25, 0.5, 0.75 and $1 \mathrm{mM}$ of STS for $1 \mathrm{~h}$ pulse treatment. A separate set of flowers kept in distilled water was designated the control group. STS treatment resulted in improved flower longevity besides maintaining higher fresh and dry mass, water content and floral diameter. Conversely, total phenols, lipid peroxidation and lipoxygenase (LOX) activity decreased. The flowers treated with STS showed a significant increase in the activity of antioxidant enzymes such as superoxide dismutase (SOD), catalase (CAT) and ascorbate peroxidase (APX). Amongst various grades used, $0.5 \mathrm{mM}$ STS was found to be most effective in enhancing the flower longevity by 1.5 days. The present study reveals that STS maintains lower LOX activity, thereby increased membrane stability index by improving the activity of antioxidant enzymes.
\end{abstract}

Key words: antioxidant enzymes; catalase; flower longevity; lipoxygenase; superoxide dismutase

\section{INTRODUCTION}

Onagraceae is a dicotyledonous family of flowering plants that harbors important and vide range of ornamentals. Amongst these, Clarkia pulchella is grown throughout the world as an ornamental plant and can be used as cut flower because of its showy and attractive color. Hence, it has a great potential for flower market. However, its short flower longevity creates a big hurdle in its potential ornamental value. Flower senescence is often a very complex process involving many cellular and biochemical changes. The biochemical changes are regulated by several plant growth regulators such as ethylene, cytokinins and gibberellins. Amongst the growth regulators, ethylene is, in some species, the primary regulator of flower senescence and petal wilting is accompanied by a peak in ethylene production (Nichols 1977; Silva et al. 2015). Ethylene serves to initiate and to regulate the processes that finally lead to programmed organ death. The early onset of ethylene synthesis during senescence of carnations and the retardation of senescence by inhibitors of ethylene biosynthesis indicate the importance of ethylene in this process. It has been reported in several species such as carnation, Petunia and Ipomoea that ethylene antagonists delay the process of flower senescence by regulating the ethylene biosynthesis and action (Ichimura \& Hiraya 1999). Amongst ethylene antagonists, silver thiosulphate (STS), aminooxyacetic acid (AOA), 1-methyl cyclopropene (1-MCP), aminoethoxyvinyl glycine (AVG) and norbornadiene (NBD) are the most important in modulating the process of flower senescence. The activity of 1-aminocyclopropane-1-carboxylic acid (ACC) synthase (typically the rate-limiting step) is markedly reduced by inhibitors of pyridoxal phosphate enzymes, such as AOA and AVG (Baker et al. 1977). As AOA prevents ethylene biosynthesis, it has limited value, offering little protection in ethylene-polluted environments (Fujino et al. 1980; Harkema \& Struijlaart 1989). The cyclic olefin, 
NBD, also inhibits ethylene action, presumably by competitively inhibiting the ethylene binding site (Sisler et al. 1983). Being carcinogenic and with foul odour make it unfit for the use in cut flowers as ethylene antagonist (Reid \& Wu 1992). It has been found that silver acts at the first step of ethylene response pathway, possibly at the ethylene receptor protein (Beyer 1976, Kovacic et al. 1991; Knee 1995). STS has also been widely used as an experimental probe for ethylene involvement in plant processes, thus making it the most effective ethylene antagonist (Abeles et al. 1992; Knee 1995). The application of silver ions to the flowers substantially reduced ethylene binding. Silver is supplied as an ionic complex with STS, which is more mobile in plant tissue and less phytotoxic. Carnation flowers treated with STS did not exhibit the climacteric rise in ethylene production nor did they accumulate ACC. This results in an extended vase life (Veen 1986; van Altvorst \& Bovy 1995). The upsurge of ethylene production regulates the activity of proteases, leading to overall protein degradation. The present study was undertaken to get knowledge on the effect of ethylene antagonist, STS, on the flower longevity of this economically important ornamental flower.

\section{MATERIALS AND METHODS}

\section{Experimental setup}

Detached flowers of local genotype $C$. pulchella Pursh (purple passion) were harvested at $8 \mathrm{AM}$ from the uniform and healthy plants growing in the Kashmir University Botanic Garden (KUBG). The cut shoots with flower buds (at 1 day before anthesis) were immediately brought to the laboratory, cut to a uniform pedicel length of $5 \mathrm{~cm}$ and divided into six sets. The buds were kept for $1 \mathrm{~h}$ with their pedicels immersed in STS solution of different concentrations $(0.1,0.25,0.5,0.75$ and $1 \mathrm{mM}$, respectively) and then transferred to distilled water (DW), one flower in one vial. A separate set of floral buds held in DW served as control. For each treatment, there were 25 replicates (flowers). The treatment effects were evaluated by keeping the experimental setup under natural conditions in the laboratory with temperature ranging from $21 \pm 2{ }^{\circ} \mathrm{C}$ under cool white fluorescent light with a mix of diffused natural light $\left(10 \mathrm{~W} \cdot \mathrm{m}^{-2}\right)$ for $12 \mathrm{~h}$ a day and relative humidity (RH) of $60 \% \pm 10 \%$. The day of transfer of buds to DW was designated as day zero (D0). All measurements and analyses were performed on days 2 and 4 of transfer to DW. All chemical analyses were determined on fresh tissue samples.

\section{Floral diameter}

Floral diameter of 10 flowers from each treatment was taken as mean of two perpendicular measurements of the flower.

Fresh mass (fm), dry mass (dm) and water content For fresh mass determination, 5 flowers were taken at the fully open stage, whereas the same flowers were oven dried at $70{ }^{\circ} \mathrm{C}$ for $48 \mathrm{~h}$ for calculation of dry mass. The water content $(\mathrm{g})$ was measured as difference between fresh and dry mass.

\section{Protein estimation}

Soluble proteins were estimated by the method of Lowry et al. (1951) using bovine serum albumin (BSA) as standard.

\section{Estimation of total phenols}

Total phenols were estimated by the method of Swain and Hillis (1959) using gallic acid as standard.

\section{Membrane stability index (\%MSI)}

The electrolyte leakage was calculated by incubating $500 \mathrm{mg}$ of petal tissue in $25 \mathrm{ml}$ of deionized water at $25^{\circ} \mathrm{C}$ for $30 \mathrm{~min}$ and $100{ }^{\circ} \mathrm{C}$ for $15 \mathrm{~min}$ (Sairam 1994). The conductivity of the samples incubated at $25^{\circ} \mathrm{C}$ was designated as $\mathrm{Cl}$ and those incubated at $100{ }^{\circ} \mathrm{C}$ was designated as $\mathrm{C} 2$ after recording the values on Elico CM180 Conductivity meter. Membrane stability index (MSI) was calculated as follows:

$$
\mathrm{MSI}=\left\lfloor 1-\frac{\mathrm{C} 1}{\mathrm{C} 2}\right\rfloor \times 100
$$

Where $\mathrm{C} 1$ is the conductivity measured on samples without heating and $\mathrm{C} 2$ is the conductivity of samples measured after $100{ }^{\circ} \mathrm{C}$ treatment.

\section{Lipid peroxidation}

Lipid peroxidation was determined by the method of Heath and Packer (1968). Petal tissue (250 mg) was homogenized in $7.5 \mathrm{ml}$ of $0.1 \%$ trichloroacetic acid (TCA) and centrifuged at $15,000 \times \mathrm{g}$ for $10 \mathrm{~min}$ under refrigeration. One milliliter of supernatant was taken and mixed with $4 \mathrm{ml}$ of $0.5 \%$ thiobarbituric acid (TBA) diluted in TCA (20\%). The reaction was started by incubating the mixture at $95{ }^{\circ} \mathrm{C}$ 
in water bath for $25 \mathrm{~min}$. Reaction was ended by placing the test tubes in ice. Absorbance was recorded at 532 and $600 \mathrm{~nm}$. Nonspecific absorbance at $600 \mathrm{~nm}$ was subtracted from the value at $532 \mathrm{~nm}$. The TBA content was calculated using its absorption coefficient $(\varepsilon)$ of $155 \mathrm{mmol}^{-1} \mathrm{~cm}^{-1}$.

\section{Catalase (CAT) assay}

Catalase (CAT) activity was estimated by the method of Aebi (1984). Petal tissue (1 g) was homogenized in $100 \mathrm{mM}$ potassium phosphate buffer (pH 7.0) containing $1 \mathrm{mM}$ EDTA. The reaction mixture contained $50 \mathrm{mM}$ potassium phosphate buffer ( $\mathrm{pH}=7.0$ ), $12.5 \mathrm{mM} \mathrm{H}_{2} \mathrm{O}_{2}, 50 \mu \mathrm{l}$ enzyme extract and distilled water to make the volume to $3 \mathrm{ml}$. Reaction was started by adding $\mathrm{H}_{2} \mathrm{O}_{2}$, and the CAT activity was determined by the consumption of $\mathrm{H}_{2} \mathrm{O}_{2}$ for $3 \mathrm{~min}$ at $240 \mathrm{~nm}$ and was expressed as $\mu \mathrm{mol} \mathrm{H}_{2} \mathrm{O}_{2} \mathrm{~g}^{-1} \mathrm{fm}$.

\section{Superoxide dismutase (SOD) assay}

Petal tissue $(1 \mathrm{~g})$ was homogenized with $0.1 \mathrm{mM}$ potassium phosphate buffer ( $\mathrm{pH}$ 7.8) containing $0.1 \mathrm{mM}$ ethylenediaminetetraacetic acid (EDTA), $1 \%$ PVP and $0.5 \%(\mathrm{v} / \mathrm{v})$ Triton X-100. The homogenate was centrifuged at $15,000 \times \mathrm{g}$ for $10 \mathrm{~min}$. The supernatant was filtered through Miracloth and used for the enzyme assay.

The activity of superoxide dismutase (SOD) was measured using the method of Dhindsa et al. (1981) by monitoring the inhibition of photochemical reduction of nitroblue tetrazolium (NBT). The reaction mixture contained $50 \mathrm{mM}$ sodium carbonate, $75 \mu \mathrm{M}$ NBT, $0.1 \mathrm{mM}$ EDTA, $13 \mathrm{mM}$ methionine in $50 \mathrm{mM}$ phosphate buffer $(\mathrm{pH} \mathrm{7.8)}$ and $0.1 \mathrm{ml}$ of the enzyme extract in a final volume of $3 \mathrm{ml}$. The reaction was started by adding $1 \mu \mathrm{M}$ riboflavin and placing the test tubes in water bath at $25^{\circ} \mathrm{C}$ and illuminating with a $30 \mathrm{~W}$ fluorescent lamp. The reaction was stopped by switching off the light and keeping the test tubes in darkness. Identical test tubes which were not illuminated served as blanks. Absorbance was measured at $560 \mathrm{~nm}$ and one unit of SOD activity was defined as the quantity of the enzyme that inhibits the photo reduction of NBT to blue formazan by $50 \%$ as compared to the reaction mixture kept in dark without the enzyme extract. The SOD activity was expressed as units $\min ^{-1} \cdot \mathrm{g}^{-1} \mathrm{fm}$.

\section{Lipoxygenase (LOX) activity}

Lipoxygenase (LOX) activity was determined by the method of Axerold et al. (1981). Petal tissue $(1 \mathrm{~g})$ was homogenized in extraction buffer containing $50 \mathrm{mM}$ potassium phosphate buffer $(\mathrm{pH} 6.5)$, $10 \%$ polyvinyl pyrrolidone (PVP), $0.25 \%$ Triton X100 and $1 \mathrm{mM}$ phenylmethanesulfonyl fluoride (PMSF). One milliliter of reaction mixture contained $50 \mathrm{mM}$ Tris- $\mathrm{HCl}$ buffer (pH 6.5) and $0.4 \mathrm{mM}$ linoleic acid. The reaction was started by adding $10 \mu 1$ of crude petal extract to the reaction mixture and absorbance was recorded at $234 \mathrm{~nm}$ for $5 \mathrm{~min}$ and activity was expressed as $\mu \mathrm{mol} \cdot \mathrm{min}^{-1} \cdot \mathrm{mg}^{-1} \mathrm{fm}$ in the flower petals.

\section{Ascorbate peroxidase (APX)}

APX activity was assayed using a modified method of Nakano and Asada (1981) APX activity was determined from the decrease in absorbance at $290 \mathrm{~nm}$ due to oxidation of ascorbate in the reaction. $1 \mathrm{~mL}$ assay mixture contained $50 \mathrm{mM}$ potassium phosphate buffer ( $\mathrm{pH} 7.0), 0.5 \mathrm{mM}$ ascorbate, $0.5 \mathrm{mM}$ $\mathrm{H}_{2} \mathrm{O}_{2}$, and $10 \mu \mathrm{L}$ of extract. $\mathrm{H}_{2} \mathrm{O}_{2}$ was added last to initiate the reaction, and the decrease in absorbance was recorded for $3 \mathrm{~min}$. The extinction coefficient of $2.8 \mathrm{mM}^{-1} \cdot \mathrm{cm}^{-1}$ for reduced ascorbate was used in calculating the enzyme activity that was expressed in terms of micromole $(\mu \mathrm{M})$ of ascorbate per minute per gram fresh mass.

\section{Experimental design and data analysis}

The experiments followed a completely randomized design and with at least three independent biological replicates. The entire experiment was replicated three times to minimize the variability between the variables. The data has been statistically analyzed, and LSD was calculated at $\mathrm{P}_{0.05}$ using MINITAB (v 15. 1.2-EQUINOX_Softddl.net) software.

\section{RESULTS}

Flower senescence was characterized by loss of petal turgidity and out rolling (Fig. 1). The exogenous application of STS at $0.1,0.25$ and $0.5 \mathrm{mM}$ resulted in increase of flower longevity up to approx. 1.5 days as compared to the control (Fig. 2). The longevity at 0.75 and $1 \mathrm{mM}$ decreased much below the control. The flowers treated with STS at concentrations of $0.1,0.25$ and $0.5 \mathrm{mM}$ had higher 


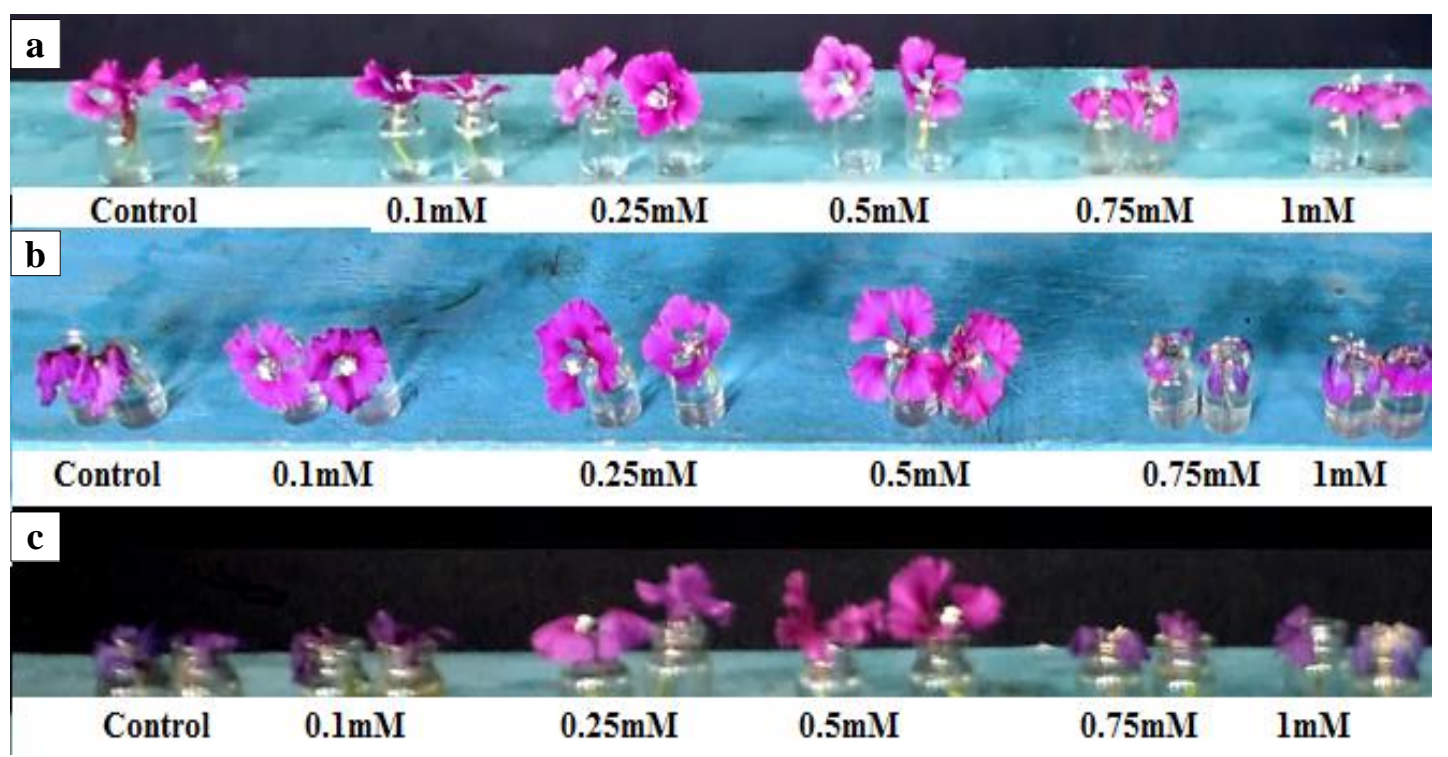

Fig. 1. Effect of silver thiosulphate on flower longevity of isolated flowers of Clarkia pulchella at day 2 (a), day 4 (b) and day 5 (c)

values of some evaluated parameters compared to the control. Flower longevity, floral diameter, fresh and dry mass, membrane stability, contents of soluble proteins as well as activities of CAT, SOD and APX increased with STS concentration up to $0.5 \mathrm{mM}$. There was a constant increase from 0.1 to $0.5 \mathrm{mM}$ of STS. After 2 and 4 days, the floral diameter was larger by $41 \%$ and $59 \%$, respectively; fresh mass was bigger by $4 \%$ and $23 \%$, respectively; and dry mass by $13 \%$ and $106 \%$ (Table 1 ). Besides, maximum water content was registered in the flowers treated with $0.5 \mathrm{mM}$ STS followed by that of 0.25 STS treatment compared to the control. Floral diameter showed a significant increase with the progression in time from D2 to D4 in the flowers treated with various grades of STS as compared to the control flowers. Maximum MSI was registered in the flowers treated with $0.5 \mathrm{mM}$ STS followed by flowers treated with $0.25 \mathrm{mM}$ STS. A significantly higher content of soluble proteins had the samples of flowers treated with various grades of STS up to $0.5 \mathrm{mM}$ concentration, thereafter a sharp decrease was noticed with the further increase in concentra- tion of STS. A steep decline in soluble protein content was registered with the progression of time from D2 to D4 irrespective of treatments. A significantly lower phenolic content was recorded in the floral buds treated with $0.5 \mathrm{mM}$ of STS when compared to control. However, a higher level of phenolic content was noticed with the further increase in concentration of STS. Lipid peroxidation decreased in the samples of flowers pretreated with $0.1,0.25$ and $0.5 \mathrm{mM}$ STS then increased (Table 1).

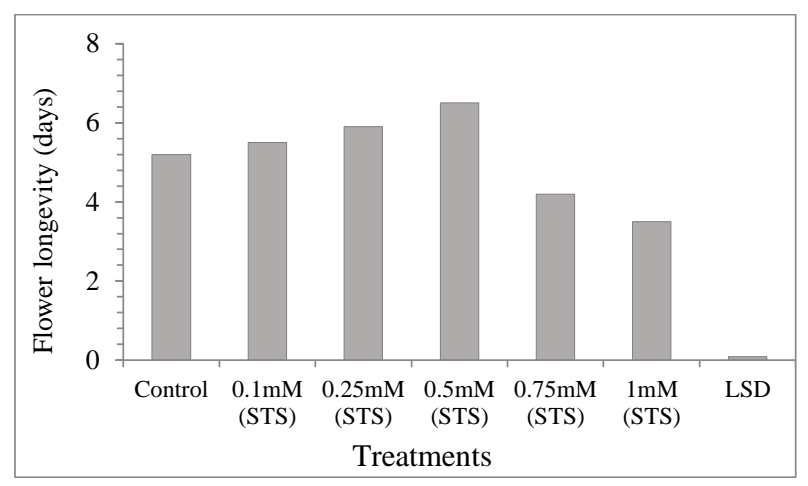

Fig. 2. Effect of silver thiosulphate on flower longevity of isolated flowers of Clarkia pulchella Pursh. 
Table 1. Effect of silver thiosulphate (1-h pulse treatment) on floral diameter, fresh mass, dry mass, water content, membrane stability, lipid peroxidation and contents of soluble proteins and total phenols in isolated flowers of Clarkia pulchella Pursh.

\begin{tabular}{|c|c|c|c|c|c|c|c|}
\hline \multirow{2}{*}{$\begin{array}{l}\text { Days of } \\
\text { transfer }\end{array}$} & \multicolumn{6}{|c|}{$\begin{array}{l}\text { Treatments with STS (in the brackets percentage of }+ \text { or }- \text { in comparison with } \\
\text { control (0 STS) }\end{array}$} & \multirow[t]{2}{*}{ LSD at $\mathrm{P}_{0.05}$} \\
\hline & 0 & $0.1 \mathrm{mM}$ & $0.25 \mathrm{mM}$ & $0.5 \mathrm{mM}$ & $0.75 \mathrm{mM}$ & $1 \mathrm{mM}$ & \\
\hline \multicolumn{8}{|c|}{ Floral diameter $(\mathrm{cm})$} \\
\hline 2 & 3.7 & 3.8 & 4.4 & $5.2(+41)$ & 3.5 & 3.3 & 0.05 \\
\hline 4 & 3.4 & 3.9 & 4.7 & $5.4(+59)$ & 3.1 & 0 & 0.07 \\
\hline \multicolumn{8}{|c|}{ Fresh mass (mg) } \\
\hline 2 & 115 & 118 & 119 & $120(+4)$ & 115 & 98 & 1.2 \\
\hline 4 & 99 & 119 & 120 & $122(+23)$ & 97 & 0 & 1.05 \\
\hline \multicolumn{8}{|c|}{ Dry mass (mg) } \\
\hline 2 & 31 & 31 & 33 & $35(+13)$ & 31 & 28 & 0.9 \\
\hline 4 & 18 & 32 & 35 & $37(+106)$ & 27 & 0 & 0.9 \\
\hline \multicolumn{8}{|c|}{ Water content (mg) } \\
\hline 2 & 84 & 87 & 86 & $85(0)$ & 84 & 70 & 1.07 \\
\hline 4 & 81 & 87 & 85 & $85(+5)$ & 70 & 0 & 1.005 \\
\hline \multicolumn{8}{|c|}{ Membrane stability index $(\%)$} \\
\hline 2 & 34 & 57 & 69 & $75(+121)$ & 34 & 33 & 1.02 \\
\hline 4 & 27 & 46 & 57 & $63(+133)$ & 29 & 0 & 1.004 \\
\hline \multicolumn{8}{|c|}{ Soluble proteins $\left(\mathrm{mg} \cdot \mathrm{g}^{-1} \mathrm{fm}\right)$} \\
\hline 2 & 2.4 & 2.9 & 3.0 & $3.4(+42)$ & 2.3 & 1.9 & 0.06 \\
\hline 4 & 1.7 & 2.1 & 2.6 & $2.8(+65)$ & 1.9 & 0 & 0.05 \\
\hline \multicolumn{8}{|c|}{ Total phenols $\left(\mathrm{mg} \cdot \mathrm{g}^{-1} \mathrm{fm}\right)$} \\
\hline 2 & 4.2 & 3.0 & 3.2 & $2.5(-40)$ & 5.0 & 5.2 & 0.04 \\
\hline 4 & 4.5 & 3.2 & 3.4 & $2.9(-36)$ & 5.2 & 0 & 0.05 \\
\hline \multicolumn{8}{|c|}{ Lipid peroxidation $\left(\mathrm{nmol} \cdot \mathrm{g}^{-1} \mathrm{fm}\right)$} \\
\hline 2 & 7.5 & 6.1 & 5.7 & $4.5(-40)$ & 6.2 & 5.4 & 0.09 \\
\hline 4 & 8.2 & 6.2 & 5.9 & $4.9(-40)$ & 7.4 & 0 & 0.03 \\
\hline
\end{tabular}

The CAT activity of the samples from flowers treated with various grades of STS was significantly higher than the corresponding samples from the control flowers, except in the flowers treated with $1 \mathrm{mM}$ STS, where the samples showed a lower CAT activity (Fig. 3a). SOD and APX activity presented a similar trend, however, a sharp decrease in SOD activity was registered also for $0.5 \mathrm{mM}$ STS (Fig. $3 \mathrm{~b}, 3 \mathrm{~d})$. The lowest value of LOX activity was registered in the samples from the treatment with $0.5 \mathrm{mM}$ STS and the highest at $1 \mathrm{mM}$ STS (Fig. 3c). The activity of APX was zero at $1 \mathrm{mM}$ STS (Fig. 3d). 

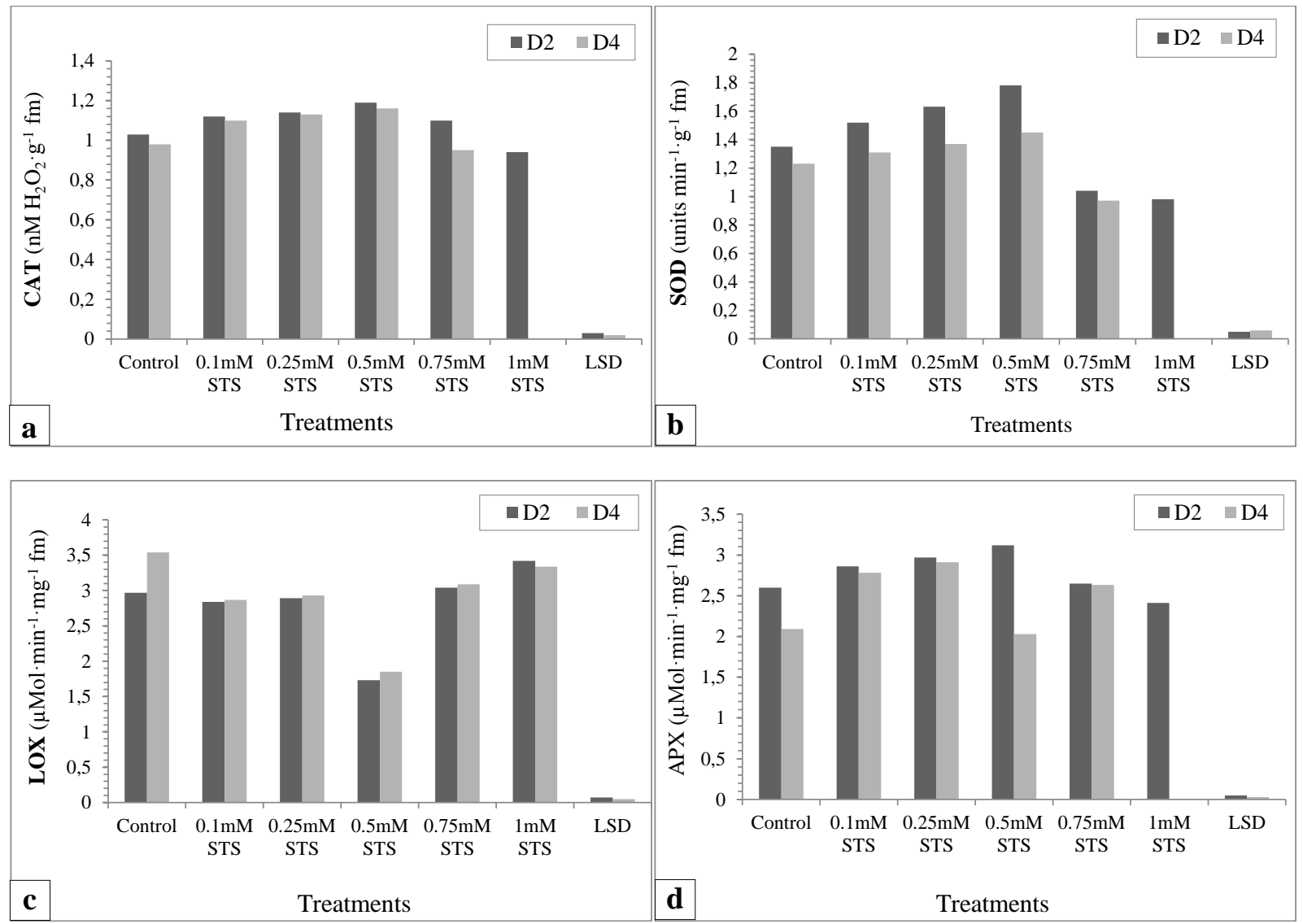

Fig. 3. Changes in the activity of enzymes in the samples of the petal tissues from the isolated flowers of Clarkia pulchella Pursh. upon treatment with different grades of STS $(0.1,0.25,0.5,0.75$ and $1 \mathrm{mM})$ : a. CAT, b. SOD, c. LOX, d. APX

\section{DISCUSSION}

The exogenous application of ethylene antagonist STS resulted in increased flower longevity when compared to flowers submerged in distilled water. The higher fresh and dry mass along with bigger flower diameter could be due to increased sugar levels in the petal tissues which in turn resulted in the decreased water potential and, hence, promoted water influx (Zang 2001; Silva et al. 2015; Iqbal et al. 2017). Our results corroborate with the earlier findings on Consolida, Petunia, Dianthus, Lathyrus and Tropaeolum majus flowers (Kikuchi et al. 2003; Wawrzyńczak \& Goszczyńska 2003; Finger et al. 2004; Silva et al. 2015; Iqbal et al. 2017). Sugars have been suggested to reduce respiratory losses because of suppressed climacteric ethylene rise in certain plant tissues (Dar et al. 2014). Maximum MSI maintained in the flowers treated with STS could be due to reduced ethylene production, which directly affects the stability of the membranes. The direct effects of ethylene on membrane stability has been shown in many flowers such as Petunia, carnation and Ipomoea by increasing the permeability of the membrane, thereby leading to increased leakage of proteases from vacuole into cytoplasm (Fukuchi-Mizutani 2000). During the present study, the decreased lipid peroxidation and LOX activity at $0.5 \mathrm{mM}$ STS could be one of the reasons for improved MSI maintained by silver ions. Silver impregnation has been found to maintain membrane stability in the cut stems of carnation and Chrysanthemum (Kofranek \& Paul 1975). The increase in soluble protein content up to $0.5 \mathrm{mM}$ it is connected with regulation of ethylene response (McClellan \& Chang 2008; Shahri \& Tahir 2010). Decrease in phenols in the flowers treated with $0.5 \mathrm{mM}$ STS associated with increased flower longevity has been reported in many flowers such as Hemerocallis, Ranunculus and Dianthus (Gulzar et 
al. 2005; Shahri \& Tahir 2010; Dar et al. 2014). However, the increased level of phenols was found to be associated with increased vase life in cut rose petals (Mwangi et al. 2003).

The current investigation showed that maximum activity of antioxidant enzymes (SOD, CAT and APX) was found in the flowers treated with $0.5 \mathrm{mM}$ STS,.. It has been explained that their accumulatin coincides with decreased lipid peroxidation indirectly and reducion of intracellular reactive oxygen species (ROS) concentration directly by the silver treatment. In Pelargonium zonale, the silver resulted in enhanced activity of SOD likewise the activity of CAT was increased by the silver treatment in Bacopa monnieri. This was achieved by the conversion of ${ }^{\circ} \mathrm{O}_{2}$ to $\mathrm{O}_{2}$ and $\mathrm{H}_{2} \mathrm{O}_{2}$ and less ROS formation, respectively, in these two species by means of nanosilver treatment (Krishnaraj et al. 2012; Hatami \& Ghorbanpour 2014). Similarly, APX detoxify the ROS during the process of flower senescence by converting the toxic chemical species such as ${ }^{\circ} \mathrm{O}_{2},{ }^{\circ} \mathrm{OH}$ and $\mathrm{H}_{2} \mathrm{O}_{2}$.

\section{CONCLUSIONS}

The study suggests that exogenous application of STS at concentration of $0.5 \mathrm{mM}$ improves the flower longevity of $C$. pulchella by about 1.5 days as compared to the control, up to 6.6 days. Moreover, STS increases fresh and dry mass along with floral diameter which is connected with modifications of senescence related enzymes activity. Our study proposed that STS treatment could provide an efficient strategy for improving flower longevity of this flower to boost the economy of cut flower industry.

\section{REFERENCES}

Abeles F.B., Morgan P.W., Saltveit M.E. Jr. 1992. Ethylene in Plant Biology, second edition. Academic Press, USA, $414 \mathrm{p}$.

Aebi H. 1984. Catalase in vitro. Methods in Enzymology 105: 121-126. DOI: 10.1016/s0076-6879(84)05016-3.

Axerold B., Cheesbrough T.M., Laakso S. 1981. Lipoxygenase from soybeans. Methods in Enzymology 71: 441-451. DOI: 10.1016/0076-6879(81)71055-3.
Baker J.E., Wang C.Y., Lieberman M., Hardenburg R.E. 1977. Delay of senescence in carnations by a rhizobitoxine analog and sodium benzoate. HortScience 12: $38-39$.

Beyer E.M. Jr. 1976. A potent inhibitor of ethylene action in plants. Plant Physiology 58: 268-271. DOI: 10.1104/pp.58.3.268.

Dar R.A., Tahir I., Ahmad S.S. 2014. Sugars and sugar alcohols have their say in the regulation of flower senescence in Dianthus chinensis L. Scientia Horticulturae 174: 24-28. DOI: 10.1016/j.scienta.2014.04.003.

Dhindsa R.S., Plumb-Dhindsa P., Thorpe T.A. 1981. Leaf senescence: correlated with increased levels of membrane permeability and lipid peroxidation, and decreased levels of superoxide dismutase and catalase. Journal of Experimental Botany 32: 93-101. DOI: $10.1093 / \mathrm{jxb} / 32.1 .93$.

Finger F.L., Carneiro T.F., Barbosa J.G. 2004. Postharvest senescence of Consolida ajacis inflorescences. Pesquisa Agropecuária Brasileira 39(6): 533-537. DOI: 10.1590/s0100-204x2004000600003. [in Portuguese with English abstract]

Fujino D.W., Reid M.S., Yang S.F. 1981. Effects of aminooxyacetic acid on postharvest characteristics of carnation. Acta Horticulturae 113: 59-64. DOI: 10.17660/actahortic.1981.113.8.

Fukuchi-Mizutani M., Ishiguro K., Nakayama T., Utsunomiya Y., Tanaka Y., Kusumi T., Ueda T. 2000. Molecular and functional characterization of a rose lipoxygenase cDNA related to flower senescence. Plant Science 160: 129-137. DOI: 10.1016/s01689452(00)00373-3.

Gulzar S., Tahir I., Amin I., Farooq S., Sultan S.M. 2005. Effect of cytokinins on the senescence and longevity of isolated flowers of day lily (Hemerocallis fulva) cv. Royal crown sprayed with cycloheximide. Acta Horticulturae 669: 395-403. DOI: 10.17660/actahortic.2005.669.52.

Harkema H., Struijlaart P.F. 1989. Effect of amino-oxyacetic acid on coloration of the labellum and longevity of cut Cymbidium flowers. Acta Horticulturae 261: 293-304. DOI: 10.17660/actahortic.1989.261.38.

Hatami M., Ghorbanpour M. 2014. Defense enzyme activities and biochemical variations of Pelargonium zonale in response to nanosilver application and dark storage. Turkish Journal of Biology 38: 130 139. DOI: 10.3906/biy-1304-64.

Heath R.L., Packer L. 1968. Photoperoxidation in isolated chloroplasts: I. Kinetics and stoichiometry of 
fatty acid peroxidation. Archives of Biochemistry and Biophysics 125: 189-198. DOI: 10.1016/00039861(68)90654-1.

Ichimura K., Hiraya T. 1999. Effects of silver thiosulphate (STS) in combination with sucrose on the vase life of cut sweet pea flowers. Journal of the Japanese Society for Horticultural Science 68: 2327. DOI: $10.2503 /$ jjshs.68.23.

Iqbal N., Khan N.A., Ferrante A., Trivellini A., Francini A., Khan M.I.R. 2017. Ethylene role in plant growth, development and senescence: Interaction with other phytohormones. Frontiers in Plant Science 8: 475. DOI: 10.3389/fpls.2017.00475.

Kikuchi K., Kanahama K., Kanayama Y. 2003. Changes in sugar-related enzymes during wilting of cut delphinium flowers. Journal of the Japanese Society for Horticultural Science 72: 37-42. DOI: 10.2503/jjshs.72.37.

Knee M. 1995. Copper reverses silver inhibition of flower senescence in Petunia hybrida. Postharvest Biology and Technology 6: 121-128. DOI: 10.1016/0925-5214(94)00038-t.

Kofranek A.M., Paul J.L. 1975. The value of impregnating cut stems with high concentrations of silver nitrate. Acta Horticulturae 41: 199-206. DOI: 10.17660/actahortic.1975.41.17.

Kovacic P., Kiser P.F., Reger D.L., Huff M.F., Feinberg B.A. 1991. Electrochemistry of $\mathrm{Cu}(1)$ bipyridyl complexes with alkene, alkyne and nitrile ligands. Implications for plant hormone action of ethylene. Free Radical Research Communications 15: 143149. DOI: $10.3109 / 10715769109049134$.

Krishnaraj C., Jagan E.G., Ramachandran R., Abirami S.M., Mohan N., Kalaichelvan P.T. 2012. Effect of biologically synthesized silver nanoparticles on $\mathrm{Ba}$ copa monnieri (Linn.) Wettst. plant growth metabolism. Process Biochemistry 47: 651-658. DOI: 10.1016/j.procbio.2012.01.006.

Lowry O.H., Rosenbrough N.J., Farr A.L., Randall R.J. 1951. Protein measurement with the Folin phenol reagent. Journal of Biological Chemistry 193: 265-275.

McClellan C.A., Chang C. 2008. The role of protein turnover in ethylene biosynthesis and response. Plant Science 175: 24-31. DOI: 10.1016/j.plantsci.2008.01.004.

Mwangi M., Chatterjee S.R., Bhattacharjee S.K. 2003. Changes in the biochemical constituents of "Golden gate" cut rose petals as affected by precooling with ice cold water spray, pulsing and packaging. Journal of Plant Biology 30: 95-97.

Nakano, Y., Asada, K. 1981. Hydrogen peroxide is scavenged by ascorbate specific peroxidase in spinach chloroplasts. Plant Cell Physiol. 22(5): 867-880. DOI: 10.1093/oxfordjournals.pcp.a076232

Nichols R. 1977. Sites of ethylene production in the pollinated and unpollinated senescing carnation (Dianthus caryophyllus) inflorescence. Planta 135: 155159. DOI: $10.1007 / \mathrm{bf00387165.}$

Sairam R.K. 1994. Effect of moisture-stress on physiological activities of two contrasting wheat genotypes. Indian Journal of Experimental Biology 32: 594-597.

Shahri W., Tahir I. 2010. Comparative effect of ethylene antagonists: silver thiosulphate (STS) and aminooxy acetic acid (AOA) on postharvest performance of cut spikes of Consolida ajacis cv Violet Blue. International Journal of Agriculture and Food Science Technology 1(2): 103-113.

Silva T.P., de Araújo F.F., Oliveira L.S., Lima J.S., Finger F.L. 2015. Effect of silver and copper on Tropaeolum majus flowers senescence. Acta Horticulturae 1060: 301-306. DOI: 10.17660/actahortic.2015.1060.45.

Sisler E.C., Reid M.S., Fujino D.W. 1983. Investigation of the mode of action of ethylene in carnation senescence. Acta Horticulturae 141: 229-234. DOI: 10.17660/actahortic.1983.141.30.

Swain T., Hillis W.E. 1959. The phenolic constituents of Prunus domestica: I. The quantitative analysis of phenolic constituents. Journal of the Science of Food and Agriculture 10: 63-68. DOI: 10.1002/jsfa.2740100110.

Reid M.S., Wu M-J. 1992. Ethylene and flower senescence. Plant Growth Regulation 11: 37-43. DOI: 10.1007/bf00024431.

Van Altvorst A.C. Bovy A.G. 1995. The role of ethylene in the senescence of carnation flowers, a review. Plant Growth Regulation 16: 43-53. DOI: 10.1007/bf00040506.

Veen H. 1986. A theoretical model for anti-ethylene effects of silver thiosulphate and 2, 5-norbornadiene. Acta Horticulturae 181: 129-134. DOI: 10.17660/actahortic.1986.181.14.

Wawrzyńczak A., Goszczyńska D.M. 2003. Effect of ethylene inhibitors on longevity of cut carnations (Dianthus caryophyllus L.) and ethylene production by flowers. Journal of Fruit and Ornamental Plant Research 11: 89-98.

Zhang, Z. 2001. Role of Sucrose or STS Pulsing in the Regulation of Cut Flower Senescence of Gentiana trijlora. Ph.D. Thesis. University of Canterbury New Zealand 